\title{
Male superiority and female resistance in Indonesian fairytales themed Seven Nymphs
}

\author{
Ryan Hidayat a, 1*, Fauzi Rahman b, 2, Denik Wirawatic, 3, Muhammad Sega Sufia Purnama d, 4 \\ a, d Arsitektur, Fakultas Teknik dan Ilmu Komputer, Universitas Indraprasta PGRI \\ ${ }^{b}$ Desain Komunikasi Visual, Fakultas Bahasa dan Seni, Universitas Indraprasta PGRI \\ c Pendidkan Bahasa dan Sastra Indonesia, FKIP, Universitas Ahmad Dahlan \\ 1ryansastra3@gmail.com*; fauzierachman20@yahoo.com; denik@pbsi.uad.ac.id; agesI25@gmail.com \\ *korespondensi penulis
}

\begin{tabular}{ll}
\hline Article's information \\
\hline History: & $: 6$ Februari 202I \\
Submitted & $:$ 26 Maret 202I \\
Revised & $: 30$ April 202I \\
Published & \\
\hline
\end{tabular}

Kata kunci:

Ketahanan laki-laki

Resistensi Wanita

Dongen Indonesia

Bidadari

Sastra Komperatif

\section{ABSTRAK}

Kisah Tujuh Bidadari yang tersebar di Indonesia mengandung banyak kesamaan mulai dari pengenalan cerita, konflik, puncak konflik, dan penyelesaian. Kisah tujuh bidadari selalu menggambarkan mereka tidak berdaya di hadapan manusia ketika selendang mereka dicuri. Tujuan penelitian ini adalah untuk menunjukkan bagaimana superioritas dan ketahanan laki-laki yang direpresentasikan dalam cerita rakyat bertema tujuh bidadari. Metode yang digunakan dalam penelitian ini adalah metode analisis isi dengan teknik sastra komparatif dan sosiologis. Data diambil dari cerita berjudul Jaka Tarub, Telaga Bidadari, Arya Menak, Raja Omas, dan Mahligai Keloyang. Ceritanya memiliki alur yang mirip, tetapi berasal dari daerah yang berbeda. Hasil penelitian dan analisis menunjukkan bahwa keunggulan lakilaki mulai terlihat dari aksi-aksi dalam cerita yang mengambil selendang (sayap) bidadari. Dengan kejadian tersebut, sosok peri yang diceritakan dalam semua data penelitian digambarkan tidak memiliki kekuatan untuk melawan, sehingga tanpa pilihan lain, mereka harus rela menjadi istri dari seorang pria yang mencuri selendang mereka. Namun, pada wanita (bidadari), terdapat potensi kekuatan dan ketahanan dalam menghadapi kehidupan barunya di dunia. Semua pria yang berniat menikahi bidadari dalam cerita dibuat tak berdaya dan menuruti segala macam syarat dan larangan yang diajukan oleh nimfa jika ingin menikahi mereka. Akhirnya dalam analisisnya, keseluruhan cerita berakhir dengan perpisahan antara laki-laki dan istrinya (bidadari) karena kesepakatan di awal dilanggar oleh tokoh laki-laki.

Key word:

Male superiority

women resistance

Indonesian fairytales

nymph

comparative literature

\section{ABSTRACT}

Story of Seven Nymphs spread in Indonesia implies many similarities starting from the introduction of stories, conflicts, the peak of conflict, and settlement. Story of seven nymphs always describes them as helpless before men when their shawls stolen. The aim of this study is to show how male superiority and resistance of women represented in folklore stories themed seven nymphs. The method used in this study is the content analysis method with comparative literature and sociological literature technique. The data taken from story titled Jaka Tarub, Telaga Bidadari, Arya Menak, Raja Omas, and Mahligai Keloyang. The story have similar lines, but comes from different regions. The results of the research and analysis show that the superiority of men has begun to seen from the actions in the story that took the nymph's shawl (wings). With that event, the nymphs figure told in all research data described as having no power to fight, so that without other choices, they must be willing to be the wife of a man who stole their shawl. However, in women (nymphs), there is the potential for strength and endurance in facing their new life in the world. All men who intend to marry nymphs in the story made helpless and obey all kinds of conditions and restrictions proposed by the nymphs if they want to marry them. Finally, in the analysis, the overall story ends in the separation between the man and his wife (the nymphs) because the agreement at the beginning violated by the male character.

Copyright (C) 2018 Universitas Ahmad Dahlan. All Right Reserved 


\section{Introduction}

Folklore is living among the peoples. Usually, folklore told from generation to generation (L. Y. Fang, 20II). The main characteristic of folklore is contains a lot of fantasy, imagination and delusion that far from human logic (J. C. Bottom, 1965). One of the famous folklore in Indonesia is nymphs down to earth to take a bath at the river or lake. Many of Indonesian people knows about Jaka Tarub. In that story, nymphs down to earth to take a bath with the sisters. Jaka Tarub falling in love with one of the nymph and he stole her shawl so she can't go back to the sky (heaven). She stayed on earth because her shawl is missing and left behind by her sisters. Suddenly, Jaka Tarub show up and asked her to be his wife. With certain conditions, nymph married by Jaka Tarub.

Besides Jaka Tarub, many folklores has same plot like Telaga Bidadari. Arya Menak, Raja Omas and Mahligai Keloyang. All of this folklore has same plot but adapted by their own regions (Rahman, 2018). Story of seven nymphs with one man spread in Indonesia implies same things from the plot, pattern and ending. From identical plot, there is a gender issue. From the story, we look how women in this case a nymph cannot do anything about a man (shawl thief). In every story about nymph, they always describe as a creature who weak in front of human when their shawl is stolen.

Every single trick is use to married with the nymph. It describe how superiority of man show in the story of nymph (women). Besides, even in their weakness, nymphs have ability to face every test in their life. Based on illustration of nymph folklore and patriarchy culture that appear and attach in each of plot, we suggest a comprehensive comparative literature study so representation of superiority of a man and weakness of women can be explains holistically. (S. Endraswara, 20II) take opinion of Francoist Jost, there are four steps in comparative literature study, which are comparison between literature, study of literature, analysis of literature civilization, and analysis comparative between genre.

\section{Method}

This research is use qualitative method with content analysis technic. Content analysis use to understand symbolic massages from plan or text-in this case, superiority of man and patiently of women in nymph themed folklore. Content analysis is a research method to get result from documents (Flick \& Schreier, 20I4) said that content analysis can used as a valid method and replicable to make a specific conclusion from the text. Literature approach used in this research is sociology literature and comparative study. In this research, there are five stories from different region took for analyzed. There are Jaka Tarub from Middle Java, Telaga Bidadari from South Kalimantan, Arya Menak from East Java, Raja Omas from North Sumatera, Mahligai Keloyang from Riau.

The indicators described in the analysis include: plot, similarities and deferences all of the story, representation of superiority the men show at the story, and Representation of resistance of the woman in story of seven nymph.

\section{Results and Discussion}

A. Plot

Tale of Jaka Tarub

Jaka Tarub go to the forest to hunt birds. He use hollow bamboo to blow bullet to hit birds. He looks birds until Sendang Beji. In here, he sees nymph is taking a bath. Her name is Nawangmulan. She does not find her shawl and make a competition. Who finds her shawl if it is old, they will be her parent, if it is men, he will be her husband, if it is a girl, she will be her sister. Finally, Jaka tarub married the nymph. Jaka Tarub break his promise to not open rice cover when it is cooking. After that, Nawangmulan must make a rice manually. When she did that, she finds her shawl. She return to the sky (heaven) with massage to make a stage and fire merang ketan ireng where she used to down to earth (Fariha \& Choiron, 2017).

\section{Tale of Telaga Bidadari}

Awang sukma become a leader of one region. He often walks. He is great at play flute and hunt birds. One day he goes to the forest to trap the birds. He decides to take a rest under the tree because cannot get the birds. He woke up when he hearing a laugh of nymphs. He sees nymphs are taking a bath. He try to steal one of their cloth and hide it in brood. The youngest of them finally get married with Awang Sukma. They live happily with their beautiful daughter named Kumalasari. Their happiness is disappearing when a black cock scratch a fabric. She wear the cloth and back to sky. She tells her daughter, if she wants to meet her, take seven walnut kernel, put it in the basket, shake it and play a song with flute of Awang Sukma 


\section{Tale of Arya Menak}

Arya Menak like to adventure to the forest. When full moon, he is taking a rest in side of lake. He saw nymphs down from the sky and take a bath. He took one of their cloth named Tunjung Wulan. He married her. Tunjung Wulan has ability to cook rice from a seed of rice. Her ability is gone when Arya Menak break his promise to not open the rice cover when it is cooking. After that, she must make a rice manually. Someday she finds her cloth in almost empty rice barn. She wear the cloth and go back to the sky.

\section{Tale of Raja Omas}

Raja Omas is a prince. He dumped by his six stepmothers because they do not have children. Raja Omas drawn to the river with pumpkin. He founded and raised by old women. He has tuak store. When the King visit to tuak store, he knows Raja Omas is his son. The prince decide to stay at the forest. One day, he go to the forest and suddenly he saw nymphs is taking a bath. He stole wings of the youngest nymph. After that, Raja Omas married her. One day, she found her wings and ready to go back to the sky. Before she did that, he took her son with her but Raja Omas take his son back. The youngest nymph try to go back to the sky but she not accepted again, so she change herself as Saringon, strong wind cause hard rain.

\section{Tale of Mahligai Keloyang}

Datuk Sakti is walking down the side of the river. Dawn to night of full moon, he looks a place for rest. He rests inside the forest near a clear pond. At night, he shocked with laugh of many girls. The sound is coming from near the pond. He look at them and take one of their cloth. After that, he married a girl, which the cloth hidden. They have two children, boy and girl. Datuk Sari broke his promise not tell anyone about his wife. Because of that, she is go back to the sky and left them down. Datuk Sari feel regret because his careless. They go to the clear pond at full moon to remember their mom (Sri Sabakti, 2016)

\section{B. Similarities and Differences of The Story}

The similarities and differences in the stories can be explained in table I below.

Tabel I. Different of Story Peak

\begin{tabular}{lll}
\hline No & Story & Story Peak \\
\hline I & $\begin{array}{l}\text { Jaka } \\
\text { Tarub }\end{array}$ & Jaka Tarub break the agreement to not open the cover. \\
\hline 2 & $\begin{array}{l}\text { Telaga } \\
\text { Bidadari }\end{array}$ & $\begin{array}{l}\text { The shawl has found below the stack of rice because a cock scratch that stack when Awang Sukma } \\
\text { is sleep }\end{array}$ \\
\hline 3 & $\begin{array}{l}\text { Arya } \\
\text { Menak }\end{array}$ & Arya Menak break the prohibiton with open the cover while it's cooking. \\
\hline 4 & $\begin{array}{l}\text { Raja } \\
\text { Omas }\end{array}$ & The nymph found her shawl because the men is careless \\
\hline 5 & $\begin{array}{l}\text { Mahligai } \\
\text { Keloyang }\end{array}$ & The men tell about the nymph to other \\
\hline
\end{tabular}

Similiarity of the folklore looks from the introduction of story. It starts with a men walking or adventure in the forest. They go to the forest to hunt, look for wood, gardening and look for a place for rest. The forest near pond, river or lake is a place for the nymph for take a bath. Next, the shawl, wings or their cloth stolen. She left down by her sisters who go back to the sky.

Conflict start with the men marry a nymph who lost her shawl and cannot go back to the sky. In their marriage, there are problems or promise is broke which it will make nymph found her stuff. The ending of this story is they go back to the sky because she found her stuff can make she fly. Sometimes, nymph come down to earth to meet her family.

Next, the different between the folklore is divide by two plot. One, at peak story and the ending story. The peak story is when the nymphs separate with the men. The separation happened because some factor that can be seen in the table.

Jaka Tarub and Arya Menak has same peak story, which is the men broke his promise to the nymph. The promise is about to open the rice cover when it is cooking. That term made because the nymph has a magic power 
that can change a seed of rice into a plate of rice. The men curious with the prohibition and then he open the cover and the nymph lost her power and she must cook manually so they running out of rice supply. Near to the running out, the shawl which hidden is founded by the nymph so they can go back to the sky.

In Telaga Bidadari, there is no prohibition that break by the men. It is just, the story tells about destiny cannot be avoided and lying will revealed. Awang Sukma who marry the nymph,exhaust and sleep. The black cock get in the house and scratch stack of rice. The nymph try to shoo he cock and chase it until the base of barn. In the base, she look her shawl. The nymph look sad because Awang Sukma hide her shawl. Because the shawl founded, finally she can go back to the sky.

In Raja Omas folklore, the nymph has knows that her husband keep the shawl but Raja Omas don not want to give it back because he wants to married her. In this case, Raja Omas insist the nymph to stay. Shawl will not give back even she married him or not. But, at least if she accepted the proposal, she has chance to take it back. After years Raja Omas and the nymph has children. He think, she will not return to the sky if she has children. That taught make him careless of what is he hide. The nymph not miss this chance and take her shawl so she can return to the sky.

In Mahligai Keloyang folklore, there is a term if Datuk Sakti wants to married the nymph. He must keep the secret about her life as nymph. Datuk Sakti agreed with that term and gave back her shawl. One day, he forgot the promise and broke the prohibition. Knowing it, the nymph decide to go back to the sky.

Therefore, after peak story where the men has conflict with the nymph, the plot continue to ending of story. In the end, the nymph go back to the sky. There are nymph forever in the sky or once come down to earth. This can seen in this table 2 .

Tabel 2. Diference of Story Ending

\begin{tabular}{lll}
\hline No & \multicolumn{1}{c}{ Story } & \multicolumn{1}{c}{ Story Ending } \\
\hline I & Jaka Tarub & The nymph back to the sky, onece down to earth until her child grown up. \\
\hline $\mathbf{2}$ & Telaga Bidadari & The nymph back to the sky, once down to earth. \\
\hline $\mathbf{3}$ & Arya Menak & The nymph back to the sky forever \\
\hline $\mathbf{4}$ & Raja Omas & Yhe nymph not back to the sky or down to earth but incarnate to Saringon that bother people \\
\hline $\mathbf{5}$ & $\begin{array}{l}\text { Mahligai } \\
\text { Keloyang }\end{array}$ & $\begin{array}{l}\text { The nymph back to the sky forever } \\
\end{array}$
\end{tabular}

In the table, it seen that some story has different ending. In Arya menak and Mahligai Keloyang, the nymph who has found the shawl finally return to the sky forever. It means, she never go back down to earth.

In story of Jaka Tarub and Telaga Bidadari after back to the sky, the nymph once down to earth to see their children. She has term when breastfeeding, the men must stay away from her. This condition continue until their children grown up. After that, the nymph never go back again.

In Raja Omas and the Nymph, after the nymph get the shawl and fly to the sky, he is not accepted anymore because she is too long in earth so she no longer pure.

So that, the nymph cannot go back again and nor to earth. The locals believe the nymph who cannot go back to the sky incarnate to Saringgon (kinds of windstorm) according to North Sumatera people. Saringgon always give trouble to people on earth as an expression of disappointment because not accepted in sky (Yanti \& Zabadi, 2016). 
C. Representation of Superiority The Men Show at The Story Superiority of the men in the folklore can see in the table 3.

Tabel 3. Kind of The Male Superiority

\begin{tabular}{|c|c|c|}
\hline No & Role & Superiority \\
\hline I & $\begin{array}{l}\text { Jaka Tarub } \\
\text { (Tale of Jaka Tarub) }\end{array}$ & $\begin{array}{l}\text { 1. Peeing the nymph } \\
\text { 2. Take the nymph's shawl and hide it. } \\
\text { 3. Dare to break the agreement }\end{array}$ \\
\hline 2 & $\begin{array}{l}\text { Awang Sukma } \\
\text { (Tale of Telaga Bidadari) }\end{array}$ & $\begin{array}{l}\text { I. Peeing the nymph } \\
\text { 2. Take the nymph's shawl and hide it } \\
\text { 3. Give difficult choice }\end{array}$ \\
\hline 3 & $\begin{array}{l}\text { Arya Menak } \\
\text { (Tale of Arya Menak) }\end{array}$ & $\begin{array}{l}\text { I. Peeing the nymph } \\
\text { 2. Take the nymph's shawl and hide it } \\
\text { 3. Dare to break the agreement }\end{array}$ \\
\hline 4 & $\begin{array}{l}\text { Raja Omas } \\
\text { (Tale of Raja Omas) }\end{array}$ & $\begin{array}{l}\text { I. Peeing the nymph } \\
\text { 2. Take the nymph's shawl and hide it. } \\
\text { 3. Give difficult choice } \\
\text { 4. Prohibit the nymph to take her child }\end{array}$ \\
\hline 5 & $\begin{array}{l}\text { Datuk Sakti } \\
\text { (Tale of Mahligai Keloyang) }\end{array}$ & $\begin{array}{l}\text { I. Peeing the nymph } \\
\text { 2. Take the nymph's shawl and hide it } \\
\text { 3. Give difficult choice }\end{array}$ \\
\hline
\end{tabular}

In the folklore, superiority of the men from all titled has similiarty. It is seen when they peeing the nymph when the take a bath at the lake, river or pond and stolen one of the shawl. The shawl which stolen is wear by the youngest nymph.

Scene when the men peeing and steal the shawl shows moral violation. This act can be categorization as a sexual violation used men did at women. This abuse in this categorize appear because there is a law where women is a weaker than men. The men in this case, show his superiority as a stronger side in physic and women placed at subordinate which can exploited and subdued (Fariha \& Choiron, 20I7).

Superiority of the men shows when they give a difficult choice to the nymph. It can see in Telaga Bidadari, Raja Omas and Mahligai Keloyong folklore. In that story, Awang Sukma, Raja Omas and Datuk Sakti in each story give the difficult choice to the nymph. The choice is like in telaga Bidadari, Awang Sukma give the choice to the nymph to follow him or left behind in the forest. In Mahligai Keloyang and Raja Omas, the nymph must become their wife if she wants the shawl give back. If refuse, the men will left herself in the forest. This choice is not good for the women. This scene describe women position who cannot give decision and dominate. In patriarchy convention position of the men always, dominate in decision made. Especially for something important and crucial (M. Sumera, 2013)

Representation of superiority seen when the men-in Jaka Tarub and Arya Menak folklore-break the agreement between them and his wife. The men try to break the agreement because of big curiousity.

The peak conflict at Raja Omas folklore is when the nymph found her shawl but cannot take her children with her. Raja Omas always prohibit the Nymph to take their children. He always has trick to keep his children stay on earth. This story describe how the men and the women argue for the custody. In this story, Raja Omas and the nymph. Children from their marriage must stay on earth with their father (Levi-strauss et al., I99I) because their status as human. So that the right of them must fulfilled by their father (A. S. C. Nugraheni, D. Tantri, 2013). 
D. Representation of resistance of the woman in story of seven nymph The women resistance in the folklore can see in the table 4 .

Tabel 4. Kind of Women Resistance

\begin{tabular}{lll}
\hline No & Role & Resistance \\
\hline I & Nawang Wulan & I. Live on earth and left by her sisters \\
& (Tale of Jaka Tarub) & 2. Dare to give prohibition \\
\hline 2 & Putri Bungsu & 3. Dare to give punishment when the agreement is break \\
& (Tale of Telaga Bidadari) & 2. Left her family on earth \\
\hline $\mathbf{3}$ & Bidadari & I. Live on earth and left by her sisters \\
& (Tale of Arya Menak) & 2. Dare to give prohibition \\
\hline $\mathbf{4}$ & Putri Bungsu & I. Live on earth and left by her sisters \\
& (Tale of Raja Omas) & 2. Patient and consistent with the purpose \\
\hline $\mathbf{5}$ & Bidadari & I. Try to get custody. \\
& (Tale of Mahligai Keloyang) & 2. Dare to give prohibition \\
& 3. Dare to give punishment when the agreement is break. \\
\hline
\end{tabular}

Figure of nymph describe how weak a women in front of men with all of their trick and strategy. However, women has power and resistance might be bigger than a men. Story about the nymph married with the men shows that they can live on earth, left by her sister and must life with other human they just know. This story shows how a women can adapt in hardest condition (E. Nurhayati, 2012). If we look at the nymph who used live in the sky, they live in wonderful palace, a lot of food and pleasure that can found on earth. However, in the story, the nymph can live on earth and adapt. Moreover, in Jaka Tarub, Arya Menak, and Telaga Bidadari told that their husband live in poor condition. That is mean after marriage they have ordinary live.

As a women who can adapt on earth, they can give threat to their husband as we look at Jaka Tarub and Arya Menak for example, the nymph warning her husband not to open the cover of rice while is cooking. When this prohibition violated, the consequence is separation. This is happen in Mahligai Keloyong, where the men break the warning of the nymph not tell the others about her with divorce as consequence.

In the other hand, the nymph in Raja Omas patiently waiting for the chance to take back her shawl. This consistency and patient show how women has strong will even for years. Women can see when people reckless because she can read more detail about something happen (N. Chodorow, 1974). This is seen from the story that when Raja Omas reckless the shawls can be taken.

Representation from how the nymph live on earth show that women behind their weakness show a big power. In some cases, decision and terms from the nymph imply to the men. They as if cannot do anything when the women do something. It seen from the story, when she decide to go back to the sky, the men cannot do anything. They just surrender with the condition and regret with they have done and feel superior.

\section{Conclusion}

The male superiority seen from what they did when steal the nymph shawl. It also appear when they give difficult choice to the nymph. In all story, the nymph doesn't have power to fight back so without choice, they must follow what the men said in this case, become his wife. But the nymph (women) has potential power and durability in facing her new life on earth. The men in the story must obey what term given by the women. All story ended up with separation because the men break the agreement or the lying is revealed. In the end of story, the men can't avoid his wife to go back to the sky which show that the consistency of decision women made can't be change.

\section{Acknowledgement}

Thank you to all those who have helped the completion of the writing of this article script. In addition, the author also thanks the Bahastra editorial team.

\section{References}

A. S. C. Nugraheni, D. Tantri, and Z. L. (2013). Komparasi Hak Asuh dan Hak Nafkah Anak dalam PutusanPutusan Perceraian di Pengadilan Negeri dan Pengadilan Agama di Kota Surakarta. 2(3), 6I-70. 
E. Nurhayati. (2012). Psikologi Perempuan dalam Berbagai Perspektif. Pustaka Pelajar.

Fariha, I., \& Choiron, N. F. (2017). Female Liberation in Javanese Legend "Jaka Tarub." KnE Social Sciences, I(3), 438. https://doi.org/I0.I8502/kss.vIi3.766

Flick, U., \& Schreier, M. (20I4). Qualitative Content Analysis. The SAGE Handbook of Qualitative Data Analysis, 170-183. https://doi.org/I0.4135/978I446282243.nI2

J. C. Bottom. (1965). Some Malay Historical Sources: A Bibliographical Note. South Sea Society.

L. Y. Fang. (20II). Sejarah Kesusastraan Klasik. Yayasan Obor.

Levi-strauss, K. S., Sugiharto, A., (I99I). Curug 7 bidadari. Jurnal Bahasa dan Budaya

M. Sumera. (2013). Lex et Societatis, Vol. I/No.2/Apr-Jun/20I3. I(2), 39-49.

N. Chodorow. (1974). "Family Structure and Feminine Personality". Women, Culture and Society. Stanford University Press.

Rahman, F. (2018). Perbandingan Legenda Ciung Wanara dengan Cindelaras serta Kajian Budaya Lokal. Metasastra, II(I), 3I-44.

S. Endraswara. (201 I). Metodologi Penelitian Sastra Bandingan. Bukupop.

Sri Sabakti. (20I6). PERBANDINGAN CERITA "MAHLIGAI KELOYANG” DAN "KOBA MALIN DEMAN." MAdah, 7, I.

Yanti, P. G., \& Zabadi, F. (2016). A comparative study of Indonesian fairy tales structure. Rupkatha Journal on Interdisciplinary Studies in Humanities, 8(3), 252-26I. https://doi.org/I0.21659/rupkatha.v8n3.26 